\title{
Can Teachers' Identities Come to the Rescue in the Fourth Industrial Revolution?
}

\section{Simon Bheki Khoza ${ }^{1}$ iD}

Accepted: 20 July 2021

(C) The Author(s), under exclusive licence to Springer Nature B.V. 2021

\begin{abstract}
Exploring teachers' identities while teaching in the Fourth Industrial Revolution (4IR) is essential. Such assists teachers to reflect, improving their teaching through various networks. Identities are conscious thoughts interrogating subconscious thoughts that drive teachers to understand their personal needs. Eleven teachers, registered for a Master of Education degree at a university in South Africa, were purposively selected for this study. The objective of this study was to understand teachers' identities while teaching mathematics in the 4IR. Focus-group discussions, reflective activities, and one-on-one semi-structured interviews, framed by a pragmatic case study, were used for data collection. The teachers' identities revealed that the Three Tree Rings Theory with Currere was useful when applied as the teaching framework. Such application of the theories generated three categories of teaching identities within the 4IR. Categories were societal, professional, and personal identities. The university at which these participants were registered prescribed Moodle. However, the students mostly used social media sites such as Facebook and WhatsApp. As a result, students used digital technologies even during face-to-face classes. The study concluded that, although there were elements of both personal and professional identities, the societal identity was that which drove teaching. Consequently, this study recommends that teachers should learn to reflect on, in, and for their actions, in order to address the 'what', 'how', 'who', and 'why' questions of education, natural identity, and the 4IR/5IR.
\end{abstract}

Keywords Currere · Digital technologies · Identities · Natural · Personal · Professional · Societal

\section{Introduction}

The eighteenth (18th) century was marked by radical changes, abruption, or disruptive innovations in various industries or sectors; these were called Industrial Revolutions (Schwab, 2016). The First Industrial Revolution (1IR) took place in the last half of the 18 th and the first half of the nineteenth centuries. This revolution came about through the

Simon Bheki Khoza

khozas@ukzn.ac.za

1 Discipline of Curriculum Studies and Educational Technology, School of Education, University of KwaZulu-Natal, Private Bag X 54001, Durban 4000, South Africa 
invention of the steam engine for mechanical production. The Second Industrial Revolution (2IR) took place in the nineteenth and twentieth centuries through the use of electricity for mass production. The Third Industrial (3IR) Revolution started in the twentieth century (1960s) when various types of computers and the internet were introduced in the 1990s (Khoza, 2020a). On the one hand, computers were used as teaching instructions, so that teachers could drill students to master their subject content (facts from professions) (Czerniewicz \& Brown, 2014; Sokhulu, 2020). In other words, computers were used to answer the descriptive "what" question of education, in order to address professional, discipline, or subject needs. On the other hand, the internet has been used to answer the operational 'how' question of education (Mpungose, 2020a). In other words, the internet has been used for societal communication (opinions from societies) in which teachers have shared their experiences. This suggests that the internet has been used to address societal needs. When digital technologies are used for addressing only professional or societal needs, they produce two competing identities (professional and societal) while denying the promotion of personal or pragmatic identities which are capable of answering the "who" questions of education (Biesta, 2015; Khoza, 2018; Mpungose, 2020b). The "who" question in teaching and/or learning becomes key to understanding the needs that should be addressed through the use of digital technologies. Answering this question leads to the relevant selection and usage of digital technologies/resources that address personal needs and promote pragmatic identity required by the new teaching and learning environment (Czerniewicz \& Brown, 2014; Kaushik \& Walsh, 2019; Ngubane-Mokiwa \& Khoza, 2021).

The new teaching and learning environment produced by the twenty-first century driven by mobile devices suggests the fourth industrial revolution (4IR) that address individual personal needs. The 4IR demands understanding of the personal "who" question of education (Schwab, 2016) in order to address the philosophical "why' question of education when teachers reflect (Khoza, 2019; Mpungose, 2020c). In other words, knowing and understanding who is teaching or learning drives education and demands self-reflection. This suggests that teachers should reflect on (professional), in (societal), and for (personal/ pragmatic) their teaching. In doing so, teachers will know and understand their educational identities. Teachers will then be able to choose and use relevant digital technologies that first address their needs and students' needs before professional and societal needs (Biesta, 2015; Czerniewicz \& Brown, 2014; Mpungose, 2020d). Unlike previous studies that concentrated on what (professional identities) and how (societal identities) technologies were used in the teaching of mathematics, this study explored and understood teachers' pragmatic and natural identities of teaching mathematics in the 4IR. In other words, this study has moved beyond the personal/pragmatic identity to natural identity.

\section{Teachers' Identities for the 4IR}

Teachers' identities are conscious thoughts that interrogate subconscious thoughts that drive teachers to know and understand their personal needs (Khoza, 2020a). A conscious thought is cognitive reasoning power known as the conscious mind. A subconscious thought or mind stores information about every experience humans go through to influence future actions (Khoza \& Fomunyam, 2021; Ramsøy, Michael, \& Michael, 2019). For example, if teachers repeatedly experience specific and similar actions, they can repeat those actions without concentrating on them, because they have become habits (Czerniewicz \& 
Brown, 2014; Ishiguro, 2006). Identities are formed through professional knowledge, societal skills, and/or personal values, after teachers have been exposed to specific environments that influenced them to acquire new actions (Ai, 2017; Khoza, 2017). Today, teachers are influenced by the 4IR environment which produces mobile devices that connect billions of people to powerful information access, processing, and storage network-servers (Schwab, 2016). These devices are driven by the interests of various professionals and/ or societies. When teachers use them in teaching they automatically promote the interests of these professionals and/or societies. A study conducted by Prensky (2001), supported by other studies (Budden, 2017; Czerniewicz \& Brown, 2014; Khoza \& Manik, 2015; McHaney, 2011; Mpungose, 2018), established that digital technology users are divided into digital natives (clickerati, screenagers, digital residents, Google generations, net generations, millennials...) and immigrants (digital refugees...). Digital natives are technology users who are fluent in digital technology usage. These users are interested in digitalised information called future content (displayed on screens); while digital immigrants or refugees mostly use 'legacy content' (print media) (Prensky \& Berry, 2001). Digital immigrants are technology users who learn to use digital technologies. Digital refugees are digital technology users who are forced by their organisations to use digital technologies (Khoza \& Manik, 2015). As a result, teachers' identities are created by 4IR via divisions, at the expense of original identities; however, their needs are addressed by digital technologies. Therefore, the constructs that cause the tension in the emerging 4IR are societal and professional identities.

\section{Societal Identities}

On the one hand, identities of digital native teachers are formed by nonlinear or unstructured information from opinions of specific societies, called future content, everyday, or horizontal knowledge (Hoadley, 2018; Khoza, 2019; Prensky \& Berry, 2001). In the 4IR, everyday knowledge is generated through the use of social media sites (SMSs) such as Facebook, YouTube, WhatsApp, Facebook Messenger, WeChat, Instagram, TikTok, inter alia, that connect teachers to other people. The main aim of using digital technologies is to communicate and socialise with other people in order to become members of various groups (Bozalek, Ng'ambi, \& Gachago, 2013; Mpungose \& Khoza, 2020). When teachers teach, they facilitate the process of supporting students in order to construct knowledge internally to achieve learning outcomes. All teaching and learning activities address the question of "how" learning is taking place. The process is shaped by the environment, which promotes collaboration, group work, interactivity, and peer assessment, so that teachers establish whether students have achieved learning outcomes. This facilitation process through SMSs promotes the acquisition of skills. Such skills lead to the formation of societal identity which is capable of addressing societal needs (Kisaka, 2018; Laeen et al., 2019). In other words, teachers' identities become highly dependent on how other people use digital technologies in various sectors for their own societal needs.

Teachers tend to be attracted to any trending digital technology, irrespective of where it comes from, or what it is designed for. For example, in 2009, when WhatsApp was introduced by Jan Koum and Brian Acton (erstwhile Yahoo employees) for Smartphone communication, teachers saw a teaching and learning resource to be used for educational activities. The two leading SMSs (Facebook, and YouTube) also attracted many teachers when they were introduced (Khoza \& Mpungose, 2020; Khoza, 2020b). The SMSs are 
used as a teaching and learning resource which is defined as any object or person that communicates education (Khoza \& Biyela, 2020). The same practice was observed during the introduction of other SMSs such as Facebook Messenger, WeChat, Instagram, TikTok, and others. However, the scarcity of studies that indicate positive impacts of using such digital technology to improve student academic performance is cause for concern to institutions. The aforementioned digital technologies were formally designed for societal communication outside education, without consulting educational theories (Ndlovu \& Khoza, 2021). This reveals a tension between the societal and professional identities that seems to confuse teachers when they are not aware of their teaching needs.

\section{Professional Identities}

On the other hand, identities of digital immigrant teachers are formed by linear, structured, or prescribed legacy content, school or vertical knowledge (Hoadley, 2018; Khoza, 2019; Prensky, 2001). All teaching and learning activities intend to address the "what" system of teaching (what content, resources, assessment...?). School knowledge has been taught through various learning management systems (LMSs) prescribed by institutions. Popular LMSs that have been used to transmit the legacy content or school knowledge are Modular Object-Oriented Dynamic Learning Environment (Moodle), Canvas, Web Course Tools (WebCT), Blackboard, and others (Grossi et al., 2018). LMSs consist of various activities and resources used for teaching or conferencing (Zoom, Skype and Microsoft Teams), assessment (quiz/assignments), video production (Kaltura), and others. These LMSs have been prescribed by institutions to make sure that the prescribed legacy content (Koehler \& Mishra, 2009; Mpungose \& Khoza, 2021) is on formal platforms controlled by the institutions. A teacher's role is that of an instructor who instructs students so that they master the prescribed content. When teachers administer summative assessment, they are able to establish whether students should pass or fail, based on prescribed objectives. Prescribed teaching structures, with their principles, are strictly followed by teachers, in order to instruct students according to what is mandated by their institutions. In the 4IR environment, LMSs have been advanced or improved by the introduction of new resources (Kaltura videos...). Such have been introduced to teach prescribed content (school knowledge for professional identity), while teachers facilitate acquisition of societal skills (societal identities) and personal values (personal identities) (Makumane \& Khoza, 2020; Sutherland, 2020). According to Gondwe (2020, p. 3), professional identity has introduced educational developers/technologists whose main responsibility is to "collaborate with individual instructors, academic departments and larger campus units on a range of teaching and learning activities". Educational developers seem to manage and support HEIs with the implementation of new technologies and pedagogies-based prescribed rules.

One example of a country that has used professional identity to achieve the world's best education system is Finland. However, Sahlberg (2012) notes that, although Finland had five rules of professional identity that guided the teaching and learning policies, teachers were not strict in following them. The rules in achieving the world's best education system for Finland were standardization of education (performance/standards-based education), focus on core subjects (numeracy, literacy, and science), the search for low-risk ways of reaching learning goals, the use of corporate management models as main drivers of improvement, and external test-based accountability policies. Finland had to combine these rules with elements of societal identity such as collaboration and others that promote active 
teachers. Although these rules result in a high academic performance, they favour passive teachers who may not teach their students to apply the content they have achieved. Such promotes teachers' professional identity which is driven by the use of digital technologies, in instructing students to master prescribed content, thereby passing their subject with high marks (Govender \& Khoza, 2017; Kisaka, 2018).

In South Africa, only approximately twenty per cent of schools are known as ex-Model C schools, driven by school knowledge (professional identity) (Hoadley, 2018). Most of these schools are in urban areas. Such schools are identified as well-resourced schools, while the majority of other schools are in rural areas, and identified as under-resourced schools. The under-resourced schools are known to be driven by everyday knowledge (societal identity) (Hoadley \& Jansen, 2014). As a result of the divisions of schools, higher education institutions (HEIs) have been divided into five research-intensive universities, fifteen comprehensive universities, six universities of technology, and technical vocational education and training (TVET) colleges. Most of the students from well-resourced schools are recruited by the research-intensive universities (Czerniewicz, 2018). The researchintensive universities offer degrees as the initial qualifications, while the other types of HEIs offer diplomas and/or certificates as well. The five research-intensive universities recruit students from the well-resourced schools (affluent families/communities) because they need students to complete their degrees in the prescribed period. This outcome is one of the criteria that help them always to remain in the top 500 of the university world rankings (le Grange, 2016). While university world rankings are the main drivers of the five research-intensive HEIs, the other types of HEI are driven by what their local communities need. This suggests that such a division has promoted a digital divide (Dolan, 2016) which has sustained the tension between professional (well-resourced schools and research-intensive universities) and societal identities (under-resourced schools and other types of HEI). 'Digital divide' is the phrase used to indicate people's differences in the access, use, and outcomes of digital technologies.

This tension was evident in 2020 when South Africa, like other countries, was affected by COVID-19. COVID-19 is a new variant of the coronavirus, first detected in Wuhan city in Hubei province of China (Khoza, 2020a; Sokhulu, 2020). Most countries that were affected by COVID-19 decided to shut down (lockdown) almost all their educational activities to promote physical/social distancing. The research-intensive universities and wellresourced schools had adequate and sufficiently well advanced digital technologies for online education. This helped them to conclude their 2020 academic year in 2020. Most of the other types of HEI concluded the 2020 academic year in 2021. This was because they had to train academics/teachers and students on online digital technologies, since most of these teachers had only then to fully use them for the first time (Khoza \& Mpungose, 2020; Sokhulu, 2020). This suggests the importance of introducing the 4IR resources as part of education in order for one's 4IR needs to be addressed by the 4IR technologies before one faces uncertainty.

However, what seem to be missing from the 4IR literature are studies that interrogate the tension caused by societal and professional identities, as well as educational theories that drive digital technologies. Such would promote educational values that support both teachers and students to discover and understand their personal identities (Biesta, 2015; Mpungose, 2020d). This advocates a need for theories that harmonise the tension between teaching for professional knowledge (academic performance-professional identities), and teaching for societal skills (acquisition of societal skills-societal identities), through identification of personal (individual) or pragmatic identities. Personal or pragmatic identities combine the strengths of both the professional identity that influences digital immigrants, 
and societal identity that influences digital natives. Teachers will then first address their teaching needs through relevant theories before they address professional and societal needs. Relevant theories identified for this study, which have principles of personal or pragmatic identity, are the Three Tree Rings Theory (TTTRT) (Khoza, 2013) and Currere (Pinar, 2004).

\section{Pragmatic Identity through the Three Tree Rings Theory (TTTRT) and Currere}

The word pragmatic comes from the Greek word pragma meaning realistic, logical action. The main resource or tool for pragmatic identity is the critique of pure reason or actions that form experiences and beliefs (Kaushik \& Walsh, 2019). Critiquing past experiences that are intrinsically linked to actions based on situations and contexts that shape them to beliefs, helps us to understand our personal identities and predict possible outcomes of our future actions (Maxwell, 2013). In other words, pragmatic or personal identity is about what works irrespective of influence by professional or societal actions. Pinar (2004) proposes Currere (Fig. 2) as a theory capable of critiquing personal experiences based on contextual frameworks. The context of this study is teachers' identities when using digital technologies.

As such, this study is framed by the Three Tree Rings Theory (TTTRT) as the contextual framework. The study applies digital technologies within the three educational domains or schools of thought (cognitivism, behaviourism, and constructivism) that address personal, professional, and societal needs (Fig. 1) when they are interrogated by the principles of Currere (Fig. 2).

This theory uses a tree representation (metaphor) that produces fruit to represent students or learners produced by an education system (analogous of the tree) supported by the use of digital technologies. The theory promotes important principles of teaching and learning with digital technology. The principles are cognitively driven "design of websites" (Cognitivism + design website=personal), behavioural use of LMS (Behaviourism $+\mathrm{LMS}=$ professional), and constructively used search engines and/or SMSs (Constructivism + search engines or SMSs=societal). The system/process is supposed to produce students whose identities are formed by educational values that balance professional, societal, and personal actions, in order to address professional, societal, and personal needs. Cognitivism indicates that teachers use personal cognitive processes in unconsciously (habitual actions), per digital technologies, designing their own original platforms (e.g., websites/resources) for teaching and/or learning. Behaviourism indicates that teachers consciously use digital technologies (e.g., LMSs) as prescribed by their institutions. Such technologies transmit institutional content and rules that indicate the institutionally required behaviour or actions. Constructivism indicates that teachers subconsciously use search engines and/or SMSs to facilitate learning. Students then use their experiences supported by other people's opinions or ideas to construct learning through socialisation. The 4 IR is influenced by the principles of this theory when teachers teach to promote values that address professional, societal, and personal-needs-based Currere.

Currere (Fig. 2) is an autobiographical framework for interrogating teachers' identities based on the teachers contextual situations (Pinar, 2012). Currere was found a useful framework for this study because it includes four tenets that interrogate each of the principles of TTTRT. Currere offers teachers four frames to be used in producing autobiographical or 


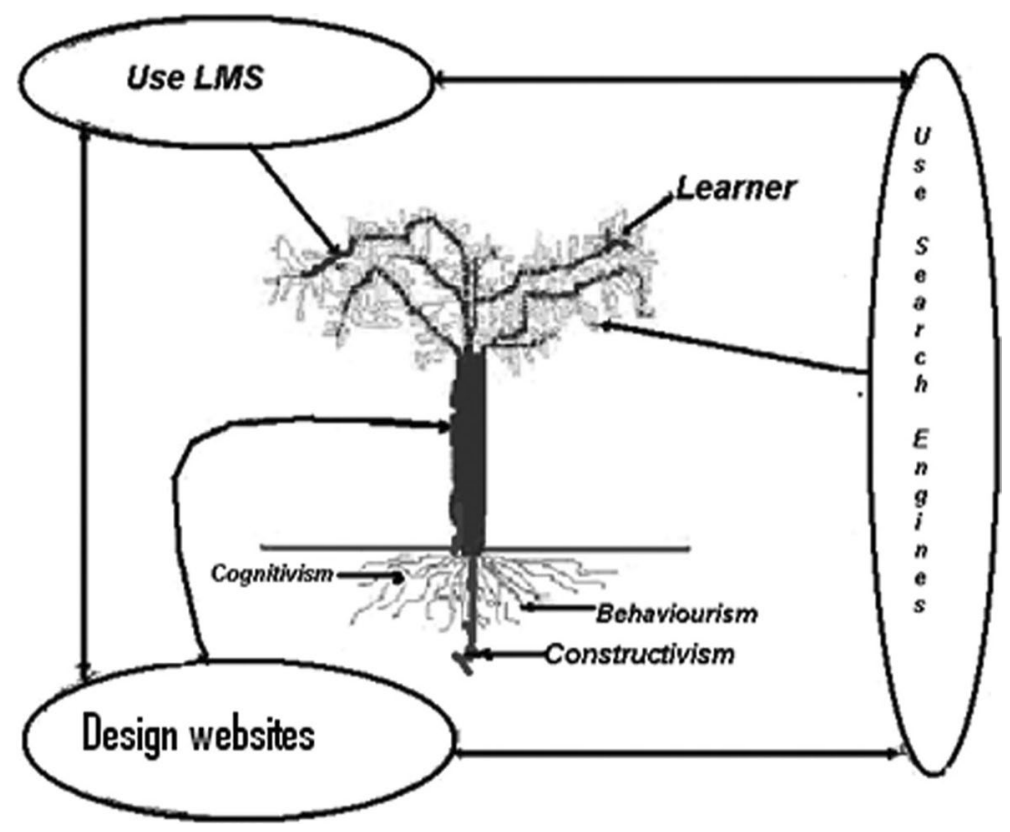

Fig. 1 The three tree rings theory (TTTRT) (Khoza, 2013, p. 63)

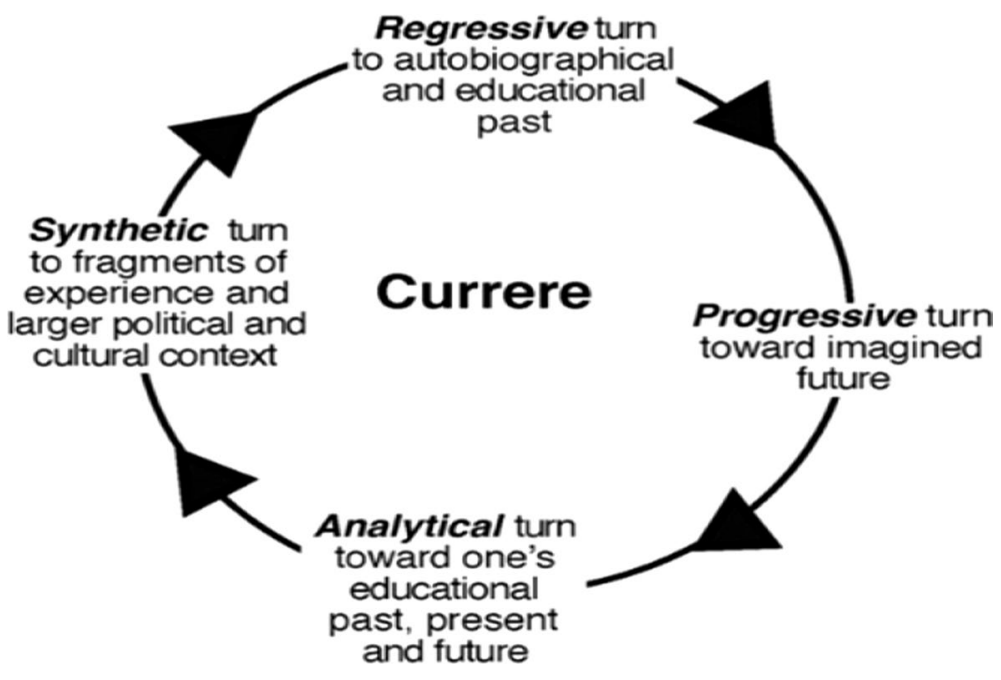

Fig. 2 Currere adapted from Pinar (2004)

personal actions. Such actions help teachers to predict possible future outcomes of digital technologies used in teaching and learning. The frames are regressive, progressive, analytical, and synthetical identity actions. These four frames indicate the moments of reflection or critique that produce new experiences and actions. A regressive moment is characterised by teachers' lived experiences to be used as data sources for actions. Academics' conscious 
minds interrogate the past subconscious mind (experiences) in order to enlarge and transform teachers' mind-systems and mind-processes to reflect on or critique present activities (Khoza, 2019). A progressive moment is characterised by teachers' imagining of possible future actions. Such is the imagination or vision of what is not yet happening. In the analytical moment, teachers interrogate the future about the past, the past about the future, and the present about both the past and future (Khoza, 2020a; Pinar, 2004). In the synthetical moment, teachers interrogate the lived present experience that reflects both the past and future experiences, in order to bring all these together to produce one meaningful action in the use of digital technologies. This suggests that the combination of these theories support the process of finding and understanding the teachers' self-identities which in turn the teachers use to support their students in also finding and understanding their self-identities. Self-identities promote individual responsibility which helps individual to address their personal (pragmatic), societal, and professional needs (Khoza, 2019).

\section{Purpose and Main Objective}

The purpose and objective of the study is to explore and understand teachers' identities of teaching mathematics in the 4IR. The teachers were registered as postgraduate students (Master of Education degree) at a university in South Africa.

\section{Research Questions}

- What are teachers' identities of teaching mathematics in the 4IR?

- Why do teachers have particular identities in teaching mathematics in the 4IR?

\section{Research Paradigm and Style}

This study used a pragmatic philosophical paradigm which combines both qualitative (societal and interpretive) and quantitative (professional and positivist) methodological paradigms to address personal needs through the interrogation of experiences (Kaushik $\&$ Walsh, 2019). Such interrogation is capable of empowering and transforming individuals by drawing from the strengths of interpretive or qualitative, and positivist or quantitative paradigms, in order to address societal and professional needs that help teachers to find and understand their personal or self-identities (Ai, 2017; Aydin-, 2013; Czerniewicz $\&$ Brown, 2014). Reality may be single or multiple, according to an individual's experiences. By means of such experiences beliefs are formed based on actions responding to specific situations and contexts. The pragmatic paradigm was useful in this study because it allowed the study to draw from the most relevant methods. Such methods were based on the purpose and objective of the study, irrespective of whether from the qualitative or quantitative methodological paradigm, as recommended by Alise and Teddlie (2010), as well as Morgan (2014). This study applied the case-study research style (which is in line with the pragmatic paradigm and its purpose) with the objective of the study, as suggested by Yin (2011). This is a case study of eleven teachers who were postgraduate students at a university in South Africa. The teachers registered for a Master of Education degree at a university in South Africa because they were concerned about their positioning in the 4IR 
in terms of their university studies and the teaching of mathematics. As a result, purposive with convenience sampling was used to select the most accessible participants. Letters were written to the gatekeepers (their university registrar and the Department of Basic Education) to explain the nature of the study (in terms of confidentiality, anonymity, voluntariness, and other ethical principles), in order to gain permission before teachers were invited to participate. Pseudonyms were used to represent teachers' real names: P1 to P11 (Participant 1 to Participant 11) were used as shown in Table 1, in order to address the ethical principle of anonymity. Table 1 presents the profiles of the participants, which highlights that the participants were from 25 to 45 years old. There were eight males and three females. Ethnically, there were six African, one Other, two Indian, and two White teachers. They were all postgraduate students. Five of the participants taught at well-resourced South African schools, while the other six taught at under-resourced schools.

\section{Data Generation/Collection and Analysis}

Reflective activities, focus-group discussion, and one-on-one semi-structured interviews were used for data collection. Each of these methods was administered twice in order to triangulate the data. Reflective activities were in the form of a questionnaire, with openended questions framed by TTTRT principles. Reflective activities were mostly used for descriptive Research Question One (What?). Focus-group discussion and one-on-one semi-structured interviews as a guide for the conversations between the researcher and participants took approximately one hour each. Each of the methods of data collection was administered twice in order to understand whether participants had been transformed by the research process. Such communication helped me to achieve rich and in-depth descriptions of the phenomenon (teachers' identities), through probing and rephrasing the questions, in order to secure responses from the participants who tended to avoid questions. Probing and rephrasing were mostly used to address the philosophical Research Question Two (Why?).

Guided analysis was used in this study, because such is capable of dealing with both the inductive (qualitative) and deductive (quantitative) processes (Samuel, 2009). In other words, guided analysis uses principles of the theoretical framework for the study

Table 1 Participant profiles

\begin{tabular}{lllll}
\hline Name & Gender & Age & Nationality & $\begin{array}{c}\text { Type of school } \\
\text { for participants }\end{array}$ \\
\hline Participant 1 (P1) & Male & 32 & African & Well-resourced \\
Participant 2 (P2) & Female & 34 & African & Well-resourced \\
Participant 3 (P3) & Male & 35 & African & Under-resourced \\
Participant 4 (P4) & Male & 35 & African & Under-resourced \\
Participant 5 (P5) & Male & 36 & African & Under-resourced \\
Participant 6 (P6) & Female & 37 & African & Under-resourced \\
Participant 7 (P7) & Male & 34 & Other & Under-resourced \\
Participant 8 (P8) & Male & 25 & Indian & Well-resourced \\
Participant 9 (P9) & Male & 26 & Indian & Under-resourced \\
Participant 10 (P10) & Female & 26 & White & Well-resourced \\
Participant 11 (P11) & Male & 45 & White & Well-resourced \\
\hline
\end{tabular}


to be combined with the issues emerging from the data (Kivunja \& Kuyini, 2017). The data collection and analysis started by using principles of TTTRT (deductive), and ended with issues emerging from the participant responses, to produce themes and categories that frame the findings. After data collection, I transcribed and read data to note emerging ideas and patterns. After identifying the patterns, I coded the data that followed similar patterns to generate potential themes. After generating the themes with categories, I checked whether the themes and categories worked in relation to the coded quotations and the whole data set. I followed an ongoing analysis process of double checking the themes and categories before I presented the findings. Guided analysis helped the study to achieve trustworthiness (Guba \& Lincoln, 2005).

Trustworthiness was addressed in terms of confirmability (neutrality-all participants knew the purpose of the study), credibility (truth value-audit trail and tape recorder), dependability (consistency-direct quotations from the participants), and transferability (applicability-by providing sufficient details of the relevant context). The limitation of the study was that it generalised the findings across a large population. However, the study helped teachers to transform and become aware of their identities. The study further discussed the challenges about identities that needed to be addressed with a follow-up study, using action research to increase future transformation.

\section{Descriptive of Findings}

The findings presented in Table 2 are framed by three themes with relevant categories. Each of the findings presented under the themes was answered (in writing) through reflective activities, and confirmed/triangulated by means of the focus-group discussions and interviews. The study also substantiated the findings by means of discussions in order to re-contextualise them with relevant literature. Responses from each participant were confirmed by other participants before they were processed. Participants' responses are important because they carry, reveal, and reflect participants' identities (Ai, 2017; Khoza, 2018; Mpungose, 2020b).

Table 2 Teachers' identities of teaching in the 4IR

\begin{tabular}{ll}
\hline THEMES & Categories \\
\hline THEME 1: Professional identity & Content presentation \\
& Objectives \\
& Moodle and facebook \\
& Assessment of learning \\
& WhatsApp, search engines, and learning activities \\
THEME 2: Societal identity & Facilitation, assessment as learning, learning outcomes \\
& Pragmatic research role, self-reflection, and assessment for learning \\
THEME 3: Personal identity & Personal aims, weblog, and WhatsApp \\
\hline
\end{tabular}




\section{THEME 1: Professional Identity}

The findings indicate that the participants had limited qualities of professional identity (content, objectives, Moodle LMS, and assessment of learning) (Koehler \& Mishra, 2009; Makumane \& Khoza, 2020) as revealed by questions on behaviourism and LMS of the TTTRT.

\subsection{Content Presentation}

P3: "Drilling learners with content is becoming impossible today because learners use social media to find relevant content from other people... The content is prescribed in the CAPS [Curriculum and Assessment Policy Statement] document and our learners are aware of that..." The majority agreed.

P5: “...even if we use Facebook pages to present content so that learners can memorise it there, the influence of other people who hate memorization of the content discourage our mathematics learners... Even us for our postgraduate studies, we prefer to use content from different sources than the one presented on Moodle learning site..." The majority agreed.

P1: "... although the obsession today is about learner-centredness expected even in the teaching of mathematics, I make sure that my Facebook and WhatsApp are dominated by mathematics content so that my learners and my friends get used to mathematics language through content and pass mathematics with high marks... behaviourism is important for high academic marks..." This was supported by P2 and P6.

These accounts suggest that the majority of participants were limited in terms of teaching mathematics content from the professional identity position. However, P1, P2, and P6 maintained the professional identity position, even if other teachers encouraged them to follow learner-centredness. The three participants supported behaviourism (content-centred) because they wanted their learners to master the content and to achieve high marks, academically. This supports the notion that professional identity is for the achievement of qualifications with good marks. It follows a strict structured way of teaching driven by the subject content with objectives (Biesta, 2015; Koehler \& Mishra, 2009; Tyler, 2013).

\subsection{Objectives}

Although objectives were prescribed in the South African CAPS document and in their course outlines, the majority of participants confused them with aims and outcomes.

P10: "Objectives are what they should achieve at the end of each lesson... Objectives are also known as outcomes or aims..." The majority agreed.

P11: "We take objectives from the policy document and learners are aware of them because they are the ones to achieve them..." The majority agreed.

P2: “...for me, objectives are what I achieve as the teacher through presenting the content so that my learners achieve learning outcomes... CAPS has these as specific aims..." This was supported by P1 and P6. 
This implies that the majority of participants were not aware that objectives are written according to teachers' intentions; and are achieved by teachers as short-term goals for performance curriculum or the content-centred approach (professional identity) (Hyland, Kennedy, \& Ryan, 2006; Khoza, 2018).

\subsection{Moodle and Facebook}

Participants were introduced to Moodle by their university, who then introduced their learners similarly to Facebook and WhatsApp.

P1: "We were using Facebook in teaching to represent Moodle before the domination of WhatsApp because our schools do not have LMSs... We have been using Facebook to display links of various sources required by our learners..." Others agreed. P4: "We, thought our learners, would love to see some prescribed link sources of information and discussion forums that are similar to our university Moodle but they do not like what is prescribed since they are influenced by WhatsApp..." The majority agreed.

P1: “...my learners work well with the prescribed GeoGebra and Facebook resources because they have prescribed content that help them to achieve high marks and enjoy mathematics even when they socialise with their friends through Facebook and WhatsApp..." This was supported by P2 and P6.

This intimates that the Moodle platform was important to the participants and influenced them to use Facebook and WhatsApp to represent the Moodle platform. However, the majority of participants indirectly trained learners because they themselves did not have formal training to understand the importance of structured or prescribed activities as the important ingredient of professional identity (Ngubane-Mokiwa \& Khoza, 2021; Shoba, 2021). Although it takes some time for people to understand the culture of structured activities, these being abstract and needing much individual concentration, especially during assessment (Khoza \& Biyela, 2020; Venter, 2019), P1, P2, and P6 seemed to support the professional identity.

\subsection{Assessment of Learning}

Assessment of learning, in terms of professional identity, aims at grading students by establishing whether they have mastered the prescribed content based on the objectives as subsections of the prescribed content (Dlamini, 2018; Mabuza \& Khoza, 2019).

P6: "Although we do not understand the meaning of lower, middle, and higher orders as prescribed by CAPS [Curriculum and Assessment Policy Statement] we think we understand summative assessment strategies... they involve tests and examinations..." Others agreed.

P5: "Although CAPS demands high scores or performance from our learners and IQMS [Integrated Quality Management System) demands high scores or performance from us as teachers we are not worried about these high scores because our communities today are only happy with us when we teach/learn through collaborations and socialisation..." The majority agreed. 
P2: “...I always achieve high in IQMS because I plan and execute the plan very well

in whatever I do and I have taught my learners to do the same all the time in order to achieve high marks..." This was supported by P1 and P6.

These accounts suggest that only P1, P2, and P6 were driven by professional identity when administrating assessment. A professional identity was signalled by assessment of learning or summative assessment/evaluation as the strictly structured system of grading people (Reddy \& le Grange, 2017). Other participants were driven by societal identity which promotes collaboration.

\section{THEME 2: Societal Identity}

These findings were generated through constructivism and search engine questions of TTTRT.

\subsection{WhatsApp, Search Engines, and Learning Activities}

Facebook and WhatsApp seemed to be a drawcard that influenced teachers to understand their societal identities.

P3: "We motivate our learners to use search engines like Google, Yahoo and others to search for relevant resources that are relevant to their given tasks... They share what they find with us and other learners through WhatsApp for discussions... They are excellent and independent in searching for the subject content which is relevant to their tasks and help them to practise the principles of democracy that involve critiquing each other's projects..." Others agreed.

P7: "As university students we are not allowed to use general search engines like our learners because they publish limited scholarly peer-reviewed publications for our assignments... We use Google Scholar and the like, but when we interact with our learners through Facebook and WhatsApp they sometimes give us powerful ideas that are even useful to our own university projects..." Others agreed.

P8: "When our learners search for information they are guided by learning outcomes that are indicated in their subject outlines... They learn through the activities that are driven by what they are sharing with us... They sometimes use and share online YouTube videos where other teachers teach online same topic for the day... We allow them to connect to others like this because we do not want to bore them since they enjoy listening other people's ideas more than our... We do not instruct but facilitate..." The majority agreed.

P6: “...even if learners use social networks or any other technology, they should follow relevant instructions and plans..." This was supported by P1 and P2.

Societal identity may be perceived by those who are or have become digital natives as their identity for the 4IR. Nevertheless, societal identity is about feeding the heart (societal) and ignoring the mind (personal) and body (professional) (AlDahdouh, 2018; Khoza, 2017). According to Tyler (2013), this practice denies students the opportunity of learning the basic foundation and transition pathways that move learners from one level to the next (Hobden \& Hobden, 2015). The majority of participants believed that when they facilitated learning they produced excellent and independent learners. However, P1, P2, and P6 were 
found to be driven by professional identity that demands instructions from teachers based on prescribed structures that may not support facilitation.

\subsection{Facilitation, Assessment as Learning, and Learning Outcomes}

The participants understood facilitation, assessment as learning (peer-assessment), and learning outcomes as some of the important ingredients of societal identity (Czerniewicz \& Brown, 2014; Venter, 2019).

P9: "When we allow learners to search their own content online and get it from others to be discussed in our face-to-face classes, we help them to understand how learning should be facilitated in the 4IR classes in order to achieve subject learning outcomes... The learning outcomes are represented by aims or specific aims in the South African CAPS document... We do not generate our own learning outcomes..." Others agreed.

P10: "We encourage learners to learn by assessing each other's projects in order to learn with each other... They do peer assessment in order to see how other achieve learning outcomes and learn to critique..." Others agreed.

P2: "Although I allow my learners to use digital technologies to search for content, I start by presenting and drilling them with the subject prescribed content before I ask them to reflect on their experiences in order to facilitate learning for the 4IR..." This was supported by P1 and P6.

These accounts demonstrate that participants used digital technologies to address the question of 'how' students or learners should learn within the 4IR environment. However, only P1, P2, and P6 seemed to combine the professional and societal identities (personal/ pragmatic identity) to address the "who" and "why" questions, as the important questions that can help teachers and students understand their identities (Khoza, 2019; Venter, 2019).

\section{THEME 3: Personal Identity}

These findings were generated through cognitive and personalised websites of TTTRT.

\subsection{Pragmatic Research Role, Self-Reflection, and Assessment for Learning}

The most important resource for personal identity is the assumption of a pragmatic role to be used for self-reflection and assessment for learning through the four moments of Currere (Akbari, 2007; Khoza, 2018; Maxwell, 2013). The pragmatic research role and selfreflections were missing in the teaching and learning of the majority of participants.

P4: "We do not have time to reflect on our teaching and learning because we have limited time to complete the syllabus especially that we use learner-centred approach which needs facilitation roles and long hours to teach one topic..." The majority agreed.

P3: "We used informal assessment as prescribed in the policy document to represent assessment for learning or formative assessment... We use informal assessment to establish what learners need in order to construct knowledge and pass their subjects..." Others agreed. 
P6: "I used to design my personalised websites based on ABSA bank space before I was introduced to Facebook and other 4IR social media sites... these are used for self-reflections and formative assessment with evaluation that improve my performance..." This was supported by $\mathrm{P} 2$.

The majority of participants used assessment for learning or formative assessment because it was prescribed in the policy document. However, P6 and P2 understood formative assessment and self-reflections as important resources of personal identity used before, during, and after lessons, to assess performance. Assessment for learning helps learners and teachers to improve their performance, because they establish what needs to be revised before, during, and after lessons. Such helps teachers with what they should design for teaching and learning.

\subsection{Personal Aims, Weblog, and WhatsApp}

Aims are long-term goals designed to produce objectives and/or outcomes (Fomunyam $\&$ Khoza, 2018). The majority of participants did not have personal aims, because they believed that CAPS did not need aims. P1, P2, and P6 had personal weblogs which they designed before they referred to Facebook and WhatsApp.

P7: "We do not have personal aims because they already indicated in the policy document and learner-centred approach replaces them with outcomes... We all have at least two WhatsApp where one is used for our learners and the other one for our friends and university mates..." The majority agreed.

P1: "CAPS has aims, specific aims (objectives), and specific skills (outcomes) prescribed... my WhatsApp and weblog communicate these to learners..." This was supported by P2 and P6.

This hints that, although the majority of participants had missed aims as the long termgoals of personal identity, P1, P2, and P6 had weblogs and WhatsApp to represent elements of personal identity. This identity is observed through habitual actions when humans engage their life activities (Czerniewicz \& Brown, 2014; Khoza, 2020b). However, P6, supported by P1, P2, and P8 indicated that he was driven by natural identity more than professional, societal, or personal identity.

P6: "I strongly believe that our experiences are informed by natural forces that help us to act in our unique ways. Our Perfect God or Creator created the world with us with our unique life programmes that natural driven to produce actions and outcomes. I believe less on what professional, social, and pragmatic spaces believe that our experiences are informed by genetic (inherited abilities from our families), environmental, and situation forces respectively. The 4IR also brings in digital technologies that naturally work well for us to address our teaching, learning, and research needs without worrying what other identities believe..." (This was supported by P1, $\mathrm{P} 2$, and P8).

This suggests another level of identity-natural identity. According to Khoza and Mpungose (2020), natural identity seems to have emerged from the 4IR technologies where humans accept any outcome of their actions, because all their actions and outcomes were created by a perfect Creator. This further suggests that teachers should reflect on their experiences in order to understand their identities before they start the process of education. 


\section{Discussion of Findings}

The findings indicate that the majority of participants were driven by societal identity. Observations of "how" other teachers teach become important actions of education to be practised. The practised actions of education are aligned with the notion of democratic practices that define quality education. The quality education is driven by "critique, unconditionality, provocation-reflection, responsibility, and the pursuit of the ethical-spiritual" (Waghid, 2019, p. 5). It was clear that the majority of participants were driven by democratic principles: even their responses used words such as "we" and "our" which suggested that they were referring to themselves as groups of teachers. Participants only emphasised the critique through peer assessment (critiques of each others' projects). Other principles were implicitly practised. For example, learners were given unconditional freedom to try any activities (constructivism, outcomes, and SMSs) of their choice in learning, and to take responsibility for their independent thoughts. According to McHaney (2011), supported by Smit (2015), the main challenge of this practice is that teachers and learners are exposed to cyberbullying, in which they may be attacked by online digital technology scams having little respect for privacy. Although provocation-reflections and ethical-spiritual practices were missing in the majority of responses, it was clear that teachers' identities were driven by societal identities. The aim of such practices addressed societal needs through the operational 'how' question, while it discouraged professional needs.

While participants were aware that Curriculum and Assessment Policy Statement (CAPS) and Integrated Quality Management System (IQMS) are important policies that must be implemented so that teachers and learners perform to a high standard when assessed or evaluated, only three participants (P1, P2, and P6) took full advantage of these policies. The three participants were able to address the descriptive "what" with personal "who" questions of education. These three participants performed better than the majority of participants in terms of their learner academic performance and IQMS for teacher evaluation. The three participants positioned themselves with the personal or pragmatic identity (reflected and critiqued "who" they were as cognitive teachers), because they combined societal (constructivism, SMSs, and collaboration with democratic practices) and professional (strict rules, behaviourism, LMSs, and content) identities (Fig. 3). This suggests that quality education for societal identity is about how the majority of teachers define it; while professional identity is about what the rules of the profession define. In terms of personal identity, quality education is about first understanding how the personal needs should be addressed; and quality education is the type of education that works for the individual person.

However, what seems to be emerging from findings of this study as its main contribution to knowledge is what this study called "natural identity" (Fig. 3). Such combines the three identities (professional, societal, and personal/pragmatic). Natural identity is the unconscious, subconscious, and conscious cognitive process of believing that all actions and their outcomes are guided by natural laws, actions, or forces. For example, even if we wish to repeat an action in the same situation and context, the action becomes unique because of the natural laws or forces. Another example can be observed when we try to teach our classes so that all our students in our classes pass our subjects with one hundred percent (100\%). If they are not naturally created by the Creator to pass with $100 \%$, not all of them will achieve such. Each action with its outcome was naturally created (P6 supported by others). This suggests that teachers should re-reflect and re-critique all the time, in order to address the philosophical "why" questions of education, becoming aware of the 


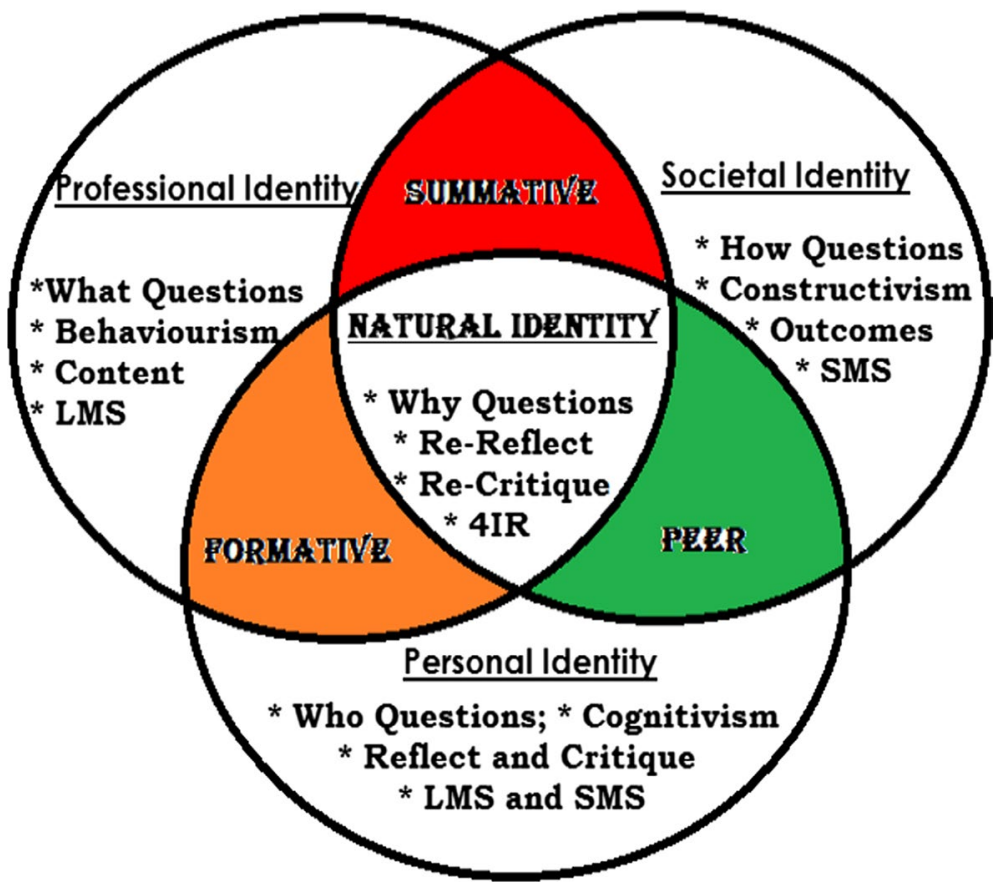

Fig. 3 Natural identity

natural identity. When they are aware of the natural identity, they can adapt to any uncertainty/novelty because they accept the natural actions and work with them, even if the professional, societal, and personal actions fail. Teachers start to accept any outcome of their actions and become able to engage their next actions after they professionally, socially, and/ or pragmatically/personally have reflected and critiqued their actions and likely outcomes.

Identities in education are driven by assessment (peer, formative, and summative) (ToroTroconis et al., 2019). Peer assessment mediates between personal and societal identities in order to help individuals to understand various learning communities. Formative assessment mediates between professional and personal identities to establish required steps to improve educational practices. Summative assessment mediates between the professional and societal identities in order to grade learners (Khoza, 2020a).

The identities seem to be hierarchical in nature (Fig. 4) because there are more teachers in lower identities than at the natural identity (Khoza \& Mpungose, 2020). Teachers are born into societies (families) where they identify as members of the societies (families). The societies peer evaluate what they do in order to indirectly/directly train them to achieve societal/family identity. The training tends to be similar to the process of mechanical production of the 1IR which influenced most families or teachers to collaborate (Budden, 2017; Toro-Troconis et al., 2019). According to P6 with others who supported him, this suggests that the teachers were influenced by the environment in which they lived, because teachers' actions are influenced by their environment (Ai, 2017).

Teachers are formally trained by educational institutions to follow the professional identity which is driven by summative evaluation that produces qualifications (Biesta, 2015; Makumane \& Khoza, 2020). Teachers learn a structured system that needs high concentration. Such may be similar to what was happening during the invention of electricity 


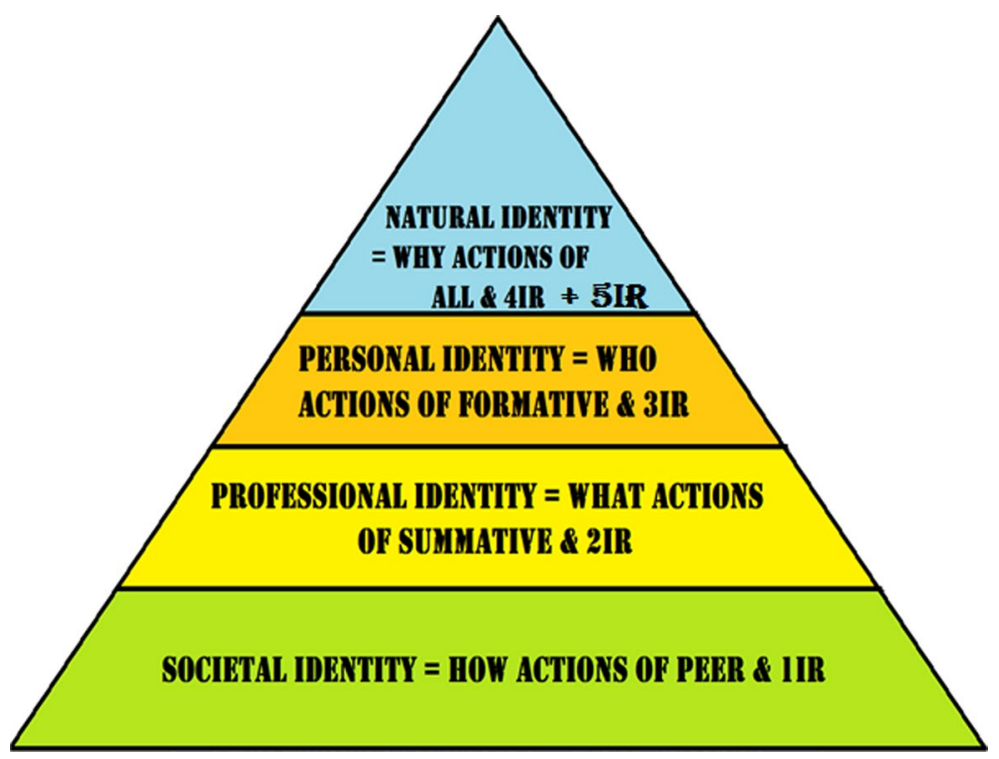

Fig. 4 Hierarch of identities

for mass production in the 2IR. Teachers come to a stage where they tend to use whatever works for them, irrespective of societal or professional actions, as identified through formative evaluation/assessment (Kaushik \& Walsh, 2019; Kivunja \& Kuyini, 2017). This reflects the 3IR, where computers and the internet were used to combine societal and professional actions to address personal needs (Sutherland, 2020). However, only three of the participants arrived at a stage/level of fully understanding the natural identity and the 4IR. Others seemed to be happy with the personal/pragmatic identity as their highest identity.

According to Schwab (2016, p. 7), 4IR technologies/resources include "the staggering confluence of emerging technology breakthroughs, covering wide-ranging fields such as artificial intelligence (AI), robotics, the internet of things (IoT), autonomous vehicles, 3D printing, nanotechnology, biotechnology, materials science, energy storage, and quantum computing, to name a few". These technologies need individuals who understand the natural identity in order to lead them. The participants became aware of the process of reflection when I conducted the second round of data collection. In other words, the data collection process transformed these teachers, who started to use the four frames/principles of Currere (regressive, progressive, analytical, and synthetical) in their lifestyles. While the majority of the participants did not fully understand the 4IR technologies, they were eager to learn.

While the teachers were becoming accustomed to the 4IR technologies, natural forces (forces of the universe) brought in the COVID-19 era which has pushed even developing countries five or ten years ahead in digitalisation. This seems to suggest a new industrial revolution - the Fifth Industrial Revolution (5IR). The 5IR which was expected in the next 5 or 10 years (Khoza \& Fomunyam, 2021), seems to have arrived and be working concurrently with the 4IR in terms of sharing digital technologies. The HEI in question, like all other HEIs in South Africa, was compelled to use its LMS (Moodle) and SMSs to facilitate e-learning because of the national lockdown. Although the HEI had approximately 78\% of students from under-resourced schools and communities where most of the participants 
were teaching, the students were not formally trained for electronic learning (e-Learning). However, the students naturally used their SMS knowledge/experience to understand Moodle for e-Learning. The students were sponsored through the HEI with data bundles by telecommunication companies such as MTN, Vodacom, Cell C, and Telkom SA to connect to the internet for e-Learning (Mpungose \& Khoza, 2021). As a result of this experience, the teachers used the same strategy on their learners in their schools, compelling their learners to use SMSs as the natural response in learning. Thus, it seems that when people are thrown in at the deep end, or face novelty/uncertainty, they naturally find their identities that help them to address their personal, social, professional, and natural needs. Natural identity remains the highest identity which is achieved by few individuals who have first achieved societal, professional, and personal/pragmatic identities (Fig. 4).

\section{Conclusion and Implications}

This study concludes that Currere was found an important resource when it was used within the principles of TTTRT, enabling teachers to understand their identities. Although the majority of participants' identities were limited to societal, professional, and personal identities, re-reflecting (responding to the questions of this study) helped participants to become aware of the natural identity generated by addressing the philosophical "why" question of the 4IR with the 5IR education. This study recommends that teachers and students/learners learn to re-reflect on, in, and for their actions, in order to address the 'what' (professional), 'how' (societal), 'who' (personal), and 'why' (philosophical) questions of education relevant to the 4IR. This suggests a need for a follow-up study using action research in order to measure the potential period taken by teachers to understand their natural identity aligned with 4IR technologies.

\section{References}

Ai, B. (2017). Constructing an academic identity in Australia: An autoethnographic narrative. Higher Education Research \& Development, 36(6), 1095-1107. https://doi.org/10.1080/07294360.2017.1303459

Akbari, R. (2007). Reflections on reflection: A critical appraisal of reflective practices in L2 teacher education. System, 35(2), 192-207. https://doi.org/10.1016/j.system.2006.12.008

AlDahdouh, A. A. (2018). Jumping from one resource to another: How do students navigate learning networks? International Journal of Educational Technology in Higher Education, 2018(1), 1-17. https:// doi.org/10.1186/s41239-018-0126-X

Alise, M. A., \& Teddlie, C. (2010). A continuation of the paradigm wars? Prevalence rates of methodological approaches across the social/behavioral sciences. Journal of Mixed Methods Research, 4(2), $103-126$.

Aydin-, A. (2013). Learner acquisition and its relationship with constructivist learner roles in a secondary education chemistry curriculum in Québec/Canada. International Education Studies, 6(7), 88-99.

Biesta, G. (2015). What is education for? On good education, teacher judgement, and educational professionalism. European Journal of Education, 50(1), 75-87.

Bozalek, V., Ng'ambi, D., \& Gachago, D. (2013). Converging institutional expertise to model teaching and learning with emerging technologies. Progressio, 35(2), 19-36.

Budden, R. (2017). Exploration of factors that inform curriculum studies students to use e-resources in conducting Masters of Education dissertations at a South African university. (Doctor of Philosophy Full research), University of KwaZulu-Natal, Durban. 
Czerniewicz, L. (2018). Inequality as higher education goes online. In N. B. Dohn, S. Cranmer, J. A. Sime, M. de Laat, \& E. Ryberg (Eds.), Networked learning: Reflections and challenges. Heidelberg: Springer Verlag.

Czerniewicz, L., \& Brown, C. (2014). The habitus and technological practices of rural students: A case study. South African Journal of Education, 34(1), 1-14.

Dlamini, M. (2018). Exploring formative assessment practices in context-based science curriculum in Swaziland: A case of Form 2 junior secondary school science. (Doctor of Philosophy), University of KwaZulu-Natal, Durban.

Dolan, J. E. (2016). Splicing the divide: A review of research on the evolving digital divide among K-12 students. Journal of Research on Technology in Education, 48(1), 16-37.

Fomunyam, K. G., \& Khoza, S. B. (2018). Managing curriculum politics of responsiveness in a Cameroonian universty. International Journal of Management and Applied Science, 4(2), 49-57.

Gondwe, F. (2020). Why we need professional educational developers. The Global Window on Higher Eduaction. Retrieved from https://www.universityworldnews.com/post.php?story=2020060415 2303587.

Govender, N., \& Khoza, S. B. (2017). Technology in education for teachers. In L. Ramrathan, L. Le Grange, \& P. Higgs (Eds.), Education studies for initial teacher development (pp. 66-79). Cape Town: Juta \& Company (PTY) Limited.

Grossi, M. G. R., Elias, M. C. A., Chamon, C. M., \& Leal, D. C. C. (2018). The educational potentialities of the virtual learning environments moodle and canvas: A comparative study. International Journal of Information and Education Technology, 8(7), 514-519.

Guba, E. G., \& Lincoln, Y. S. (2005). Paradigmatic controversies, contradictions, and emerging Confluences. In N. K. Denzin \& Y. S. Lincoln (Eds.), Handbook of qualitative research (3rd ed., pp. 191-216). SAGE Publications.

Hoadley, U. (2018). Pedagogy in poverty: Lessons from twenty years of curriculum reform in South Africa. London and New York: Routledge - Taylor \& Francis Group.

Hoadley, U., \& Jansen, J. (2014). Curriculum: Organizing knowledge for the classroom (3rd ed.). Oxford University Press Southern Africa.

Hobden, S., \& Hobden, P. (2015). A study of the transition pathways of school level scholarship recipients into work and tertiary education. South African Journal of Education, 35(3), 1-10.

Hyland, A., Kennedy, D., \& Ryan, N. (2006). Writing and Using Learning Outcomes: a Practical Guide. Bologna: European Higher Education Area (EHEA).

Ishiguro, H. (2006). Android science: Conscious and subconscious recognition. Connection Science, 18(4), 319-332.

Kaushik, V., \& Walsh, C. A. (2019). Pragmatism as a research paradigm and its implications for socialwork research. Social Sciences, 8(255), 1-17.

Khoza, S. B. (2013). Can they change from being digital immigrants to digital natives? Progressio, 35(1), 54-71.

Khoza, S. B. (2017). Master of education students' reflections which curriculum reasons are promoted or limited by skype resources? Progressio: South African Journal for Open and Distance Learning Practice, 39(2), 1-19. https://doi.org/10.25159/0256-8853/2405

Khoza, S. B. (2018). Can teachers' reflections on digital and curriculum resources generate lessons? Africa Education Review, 1(2018), 1-16.

Khoza, S. B. (2019). Lecturers' reflections on curricular spider web concepts transformation strategies. In E. N. Ivala \& C. L. Scott (Eds.), Transformation of higher education institutions in post-apartheid South Africa (Vol. 1, pp. 15-26). Routledge - Taylor \& Francis Group.

Khoza, S. B. (2020a). Academics' "why" of knowledge-building for the fourth industrial revolution and COVID-19 era. International Journal of Higher Education, 9(6), 247-258. https://doi.org/10.5430/ ijhe.v9n6p247

Khoza, S. B. (2020b). Students' habits appear captured by whatsapp. International Journal of Higher Education, 9(6), 307-317. https://doi.org/10.5430/ijhe.v9n6p307

Khoza, S. B., \& Biyela, A. T. (2020). Decolonising technological pedagogical content knowledge of first year mathematics students. Education and Information Technologies, 25(4), 2665-2679. https:// doi.org/10.1007/s10639-019-10084-4

Khoza, S. B., \& Fomunyam, K. G. (2021). Can alignment of digital resources with needs produce a new curriculum theory for teaching? In K. G. Fomunyam \& S. B. Khoza (Eds.), Curriculum theory, curriculum theorising, and the theoriser: The African theorising perspective (pp. 219-236). Leiden - Boston: Brill - SENSE.

Khoza, S. B., \& Manik, S. (2015). The recognition of 'digital technology refugees' amongst post graduate students in a higher education institution. Alternation, 17(2015), 190-208. 
Khoza, S. B., \& Mpungose, C. B. (2020). Digitalised Curriculum to the rescue of a higher education institution. African Identities, 18(4), 1-21. https://doi.org/10.1080/14725843.2020.1815517

Kisaka, S. T. (2018). An exploration of the use of moodle in teaching MED students at a university in Kenya. (Doctor of Philosophy), University of KwaZulu-Natal, Durban.

Kivunja, C., \& Kuyini, A. B. (2017). Understanding and applying research paradigms in educational contexts. International Journal of Higher Education, 6(5), 26-41.

Koehler, M., \& Mishra, P. (2009). What is technological pedagogical content knowledge (TPACK)? Contemporary Issues in Technology and Teacher Education, 9(1), 60-70.

Laeen, S. J., Ayati, M., Sani, H. J., \& Booreng, M. A. (2019). A teachers perception on localization of curriculum with emphasis on social studies lesson. International Journal of Higher Education, 8(7), 84-94.

le Grange, L. (2016). Decolonising the university curriculum. South African Journal of Higher Education, $30(2), 1-12$.

Mabuza, D. C., \& Khoza, S. B. (2019). Educators' reflections of the instructional time in JC integrated consumer science curriculum. International Journal of Home Science, 5(1), 1-7.

Makumane, M. A., \& Khoza, S. B. (2020). Educators' reasonings and their effects on successful attainment of curriculum goals. South African Journal of Higher Education, 34(2), 95-111. https://doi.org/10. 20853/34-2-3428

Maxwell, T. W. (2013). A Model for reflection to be used in authentic assessment in teacher education. JOURNAL OF THE INTERNATIONAL SOCIETY FOR TEACHER EDUCATION, 17(1), 8-17.

McHaney, R. (2011). The new digital shoreline: How Web 2.0 and Millennials are revolutionizing higher education. Sterling: VA: Stylus Publishing.

Morgan, D. L. (2014). Integrating qualitative and quantitativemethods: A pragmatic approach. Thousand Oaks: Sage

Mpungose, C. B. (2018). Exploring lecturers' reflections on the use of moodle to teach physical sciences at a South African University. (Doctor of Philosophy), University of KwaZulu-Natal, Durban.

Mpungose, C. B. (2020a). Are social media sites a platform for formal or informal learning? students' experiences in institutions of higher education. International Journal of Higher Education, 9(5), 300-311. https://doi.org/10.5430/ijhe.v9n5p300

Mpungose, C. B. (2020b). Beyond limits: Lecturers' reflections on moodle uptake in South African universities. Education and Information Technologies, 2020(4), 1-20. https://doi.org/10.1007/ s10639-020-10190-8

Mpungose, C. B. (2020c). Is moodle a platform to decolonise the university curriculum? Lecturers' Reflections. Africa Education Review, 17(1), 100-115. https://doi.org/10.1080/18146627.2018.1479645

Mpungose, C. B. (2020d). Is Moodle or WhatsApp the preferred e-learning platform at a South African university? First-year students' experiences. Education and Information Technologies, 25(2), 927-941. https://doi.org/10.1007/s10639-019-10005-5

Mpungose, C. B., \& Khoza, S. B. (2020). Postgraduate students' experiences on the use of moodle and canvas learning management system. Technology, Knowledge and Learning, 28(4), 1-16. https://doi.org/ $10.1007 / \mathrm{s} 10758-020-09475-1$

Mpungose, C. B., \& Khoza, S. B. (2021). Students' reflections on the use of zoom video conferencing technology for online learning at a South African university. International Journal of African Higher Education, $8(1), 1-18$.

Ndlovu, E. M., \& Khoza, S. B. (2021). Alternative Ways of Implementing the Curriculum. In K. G. Fomunyam \& S. B. Khoza (Eds.), Curriculum theory, curriculum theorising, and the theoriser: the african theorising perspective (pp. 320-334). Leiden - Boston: Brill - SENSE.

Ngubane-Mokiwa, S. A., \& Khoza, S. B. (2021). Using community of inquiry (CoI) to facilitate the design of a holistic e-learning experience for students with visual impairments. Education Sciences, 11(152), 1-12. https://doi.org/10.3390/xxxxx

Pinar, W. F. (2004). What is Curriculum Theory? Mahwah, N.J: Lawrence Erlbaum and Assoc.

Pinar, W. F. (2012). What is curriculum theory? Routledge.

Prensky, M. (2001). Digital natives, digital immigrants part 1. On the Horizon, 9(5), 1-6.

Prensky, M., \& Berry, B. D. (2001). Do they really think differently. On the Horizon, 9(6), 1-9.

Ramsøy, T. Z., Michael, N., \& Michael, I. (2019). A consumer neuroscience study of conscious and subconscious destination preference. Scientific Reports, 9(1), 1-8.

Reddy, C., \& le Grange, L. (2017). Assessment and curriculum. In L. Ramrathan, L. Le Grange, \& P. Higgs (Eds.), Education studies: For initial teacher development (pp. 159-173). Cape Town: Juta \& Company (Pty) LTD.

Sahlberg, P. (2012). Global educational reform movement is here! Retrieved from https://pasisahlberg.com/ global-educational-reform-movement-is-here/. 
Samuel, M. A. (2009). On becoming a teacher: Life history research and the force-field model of teacher development. In R. Dhunpath \& M. A. Samuel (Eds.), Life history research-Epistemology, methodology and representation. Rotterdam: Sense Publishers.

Schwab, K. (2016). The Fourth Industrial Revolution. Cologny: World Economic Forum®.

Shoba, M. E. (2021). Theorising teachers' experiences of teaching reading in the African context. In G. K. Fomunyam \& S. B. Khoza (Eds.), Curriculum theory, curriculum theorising, and the theoriser: the african theorising perspective (1st ed., Vol. 1, pp. 237-255). Leiden - Boston: Brill - SENSE.

Smit, D. M. (2015). Cyberbullying in South African and American schools: A legal comparative study. South African Journal of Education, 35(2), 1-11.

Sokhulu, L. H. (2020). Students' experiences of using digital technologies to address their personal research needs during the COVID-19 lockdown. African Identities, 18(3), 1-17. https://doi.org/10.1080/14725 843.2020.1801384

Sutherland, E. (2020). The fourth industrial revolution-The case of South Africa. Politikon, South African Journal of Political Studies, 47(2), 233-252.

Toro-Troconis, M., Alexander, J., \& Frutos-Perez, M. (2019). Assessing student engagement in online programmes: using learning design and learning analytics. International Journal of Higher Education, $8(6), 171-183$.

Tyler, R. W. (2013). Basic principles of curriculum and instruction. University of Chicago press.

Venter, A. (2019). Social media and social capital in online learning. South African Journal of Higher Education, 33(3), 241-257.

Waghid, Y. (2019). Qualty, dissonance and rhythm within higher education. South African Journal of Higher Education, 33(3), 1-7.

Yin, R. K. (2011). Qualitative research from start to finish. The Guilford Press.

Publisher's Note Springer Nature remains neutral with regard to jurisdictional claims in published maps and institutional affiliations. 